\title{
Legal Regulation of Territorial Defense of Ukraine and the Place of Administrative Legislation in it ${ }^{*}$
}

\author{
Anatolii Anatoliiovych Rusetskyi ${ }^{1}$, Serhii Mykolaiovych Lelet ${ }^{2}$, \\ Vladyslav Oleksiiovych Dopilka ${ }^{3}$, Nelli Yuriivna Tsybulnyk ${ }^{4}$
}

Hon. Prof. M. S. Bokarius Kharkiv Research Institute of Forensic Examinations

\section{$\underline{10.15408 / j \text { jch.v8i2.16769 }}$}

\begin{abstract}
The purpose of this article is to study the specifics, and characteristics of administrative and legal regulations of the territorial defense system of Ukraine, as well as to find the optimal model of legislative changes in the field. While writing the article the following methods were used: dialectical, logical-semantic, comparative-legal, analysis and synthesis. The issues of administrative and legal regulations of territorial defense of Ukraine, as well as the peculiarities of its legislative support is considered in the article. The author's definition of the concepts "territorial defense of Ukraine" and "administrative and legal regulation" is formed and provided with the help of the analysis of scientific views. In accordance with the subject of the article, the characteristics of the practical implementation of defense policy by special public authorities, as well as the implementation of measures of administrative and legal regulations in relation to the implementation of defense measures is defined. Proposals to improve certain procedures for the introduction, and implementation of professional activities of defense policy entities and control over it are provided, as well as the importance of effective administrative and legal support of their daily lives in the course of their duties is stressed. It is proposed to amend the relevant legislation to improve the quality of effective activities of domestic defense structures, improve the system of motivational and incentive methods that can be used to defend the Ukrainian border and domestic administrative-territorial units.

Keywords: Administrative and Legal Regulation, Territorial Defense and Legislative Support, State Bodies, Combat Units, International Cooperation.
\end{abstract}

* Received: January 19, 2020, revised: March 21, 2020, accepted: July 21, 2020, Published: August 4, 2020.

${ }^{1}$ Doctor in Law, Associate Professor, Honored Lawyer of Ukraine, Chief Research Scientist of Honored Professor M.S. Bokarius Kharkiv Research Institute of Forensic Examinations. ORCID: https://orcid.org/0000-0003-2234-4392

${ }^{2}$ Candidate of Juridical Sciences, Head of the Department of Scientific-Informational and Editorial-Publishing Activities of the State Research Institute of the Ministry of Internal Affairs of Ukraine. ORCID: https://orcid.org/0000-0001-6099-4121

3 Candidate of Law, Associate Professor, Associate Professor of the Law of the Sea Department of Odessa National Maritime University. ORCID: https://orcid.org/0000-0003-2159-6387

${ }^{4} \mathrm{PhD}$ in Law, Lecturer of the Department of Law-Enforcement Activity and Policeistics at Kharkiv National University of Internal Affairs. ORCID: https://orcid.org/0000-0002-5128-0511 Corresponding author: info@rusetskiy.name 
Anatolii Anatoliiovych Rusetskyi, Serhii Mykolaiovych Lelet, Vladyslav Oleksiiovych Dopilka, Nelli Yuriivna Tsybulnyk

\author{
Regulasi Hukum Pertahanan Wilayah Ukraina dan Tempat Legislasi \\ Administratif di dalamnya
}

\begin{abstract}
Abstrak:
Tujuan artikel ini adalah untuk mempelajari kekhususan dan karakteristik regulasi administratif dan hukum sistem pertahanan teritorial Ukraina, serta untuk menemukan model optimal dari perubahan legislatif di lapangan. Penulisan artikel ini menggunakan metode: dialektika, logissemantik, perbandingan-hukum, analisis dan sintesis. Masalah regulasi administratif dan hukum pertahanan teritorial Ukraina, serta kekhasan dukungan legislatifnya dipertimbangkan dalam artikel tersebut. Definisi penulis tentang konsep "pertahanan teritorial Ukraina" dan "peraturan administratif dan hukum" dibentuk dan disediakan dengan bantuan analisis pandangan ilmiah. Sesuai dengan pokok bahasan pasal tersebut, ciri-ciri pelaksanaan praktis kebijakan pertahanan oleh badan publik khusus, serta pelaksanaan tindakan-tindakan pengaturan administratif dan hukum sehubungan dengan pelaksanaan tindakan-tindakan pertahanan ditetapkan. Proposal untuk meningkatkan prosedur tertentu untuk pengenalan dan pelaksanaan kegiatan profesional entitas kebijakan pertahanan dan kontrol atasnya disediakan, serta pentingnya dukungan administratif dan hukum yang efektif dalam kehidupan sehari-hari guna menjalankan tugas mereka. Diusulkan untuk mengubah undang-undang yang relevan dalam rangka meningkatkan kualitas kegiatan yang efektif dari struktur pertahanan dalam negeri, meningkatkan sistem metode motivasi dan insentif yang dapat digunakan untuk mempertahankan perbatasan Ukraina dan unit administrasi-teritorial domestik.

Kata Kunci: Pengaturan Administrasi dan Hukum, Pertahanan Teritorial, Dukungan Legislatif, Badan Negara, Satuan Tempur, Kerjasama Internasional.

\section{Правовое регулирование территориальной обороны Украины и место в нем административного законодательства}

\title{
Аннотация
}

Целью данной статьи является: 1) изучение специфики и характерных особенностей административно-правового регулирования системы территориальной обороны Украины; 2) поиск оптимальной модели законодательных изменений в этой ссрере государственной деятельности. При написании статьи автора использовали такие методы, как: диалектический, логико-семантический, сравнительно-правовой, анализа и синтеза. Рассмотрены вопросы административно-правового регулирования территориальной обороны Украины, а также особенности законодательного обеспечения данной сферы государственной деятельности. С помощью анализа научных взглядов сформулировано авторское видение понятия «территориальная оборона Украины» и «административно-правовое регулирование». В соответствии с тематикой исследования: a) выделены характерные особенности практического осуществления оборонной политики специальных органов государственной власти; б) определены возможные направления реализация мер административно-правового регулирования оборонных мероприятий. Сформулированы предложения по совершенствованию отдельных процедур осуществления профессиональной деятельности субъектов проведения оборонной политики и контроля за ней. Отмечена важность эфффективного административно-правового обеспечения повседневной жизнедеятельности таких субъектов, и особенно при реализации предоставленных полномочий. Предложено внесение изменений в профильное законодательство с целью повышения качественного уровня эфффективной деятельности отечественных оборонных структур, совершенствования системы мотивировочных и поощрительных методов, которые могут применяться в целях обороны украинских границ и административно-территориальных единиц.

Ключевые слова: Административно-правовое регулирование, Территориальная оборона, Законодательное обеспечение, Государственные органы, Боевые подразделения, Международное сотрудничество. 


\section{A. INTRODUCTION}

At the present stage of development and functioning of the independent Ukrainian state, changes and reforms that are extremely important for the country's future are taking place. Among such conceptual transformations, which are certainly important for ensuring the viability of our state, it is necessary to identify the improvement of the general state of military strength and operational effectiveness of both the Armed Forces of Ukraine and territorial defense units.

The decision of the National Security and Defense Council of Ukraine dated 4 March 2016 "On the Concept of Development of the Security and Defense Sector of Ukraine" states that unresolved problems in the security and defense sector are: - "inefficiency of the mechanism to prevent and neutralize modern threats to the national security of Ukraine; incomplete process of building an effective resource management system in crisis situations threatening national security; - imperfect and ineffective interaction between central and local authorities, primarily on issues of prevention and combating terrorism" (Decree of the President of Ukraine, 2016). The lack of effective mechanisms of state regulation of territorial defense as a component of the military organization of the state has a negative impact on ensuring defense capability (Yaniuk, 2019, p. 97).

In order to achieve greater efficiency in the functioning of those armed state formations, entrusted with the implementation of territorial defense, as well as for the general benefit of the state, it is necessary to legislate a clear regulation of their activities.

The purpose of this article is to study the specific, and characteristics of administrative and legal regulations of the territorial defense system of Ukraine, as well as to find the optimal model of legislative changes in the field.

Also, the purpose of this article is to prove by scientific study the significant impact of military-political alliances on the entire global security and stability system. This is because joining NATO will be the most successful and effective step in the field of security of Ukraine, because it is almost the only means of protection against armed aggression of another state.

\section{B. METHODS}

To achieve the purpose of the research, both general scientific and special methods of scientific cognition were used. The application of these methods 
was due to a systematic approach, which made it possible to study the problems raised in the unity of their social content and legal form. Using the dialectical method, the problems that arise in the development of territorial defense in Ukraine, in particular to ensure further defense capabilities of the state, improve the activities of the Armed Forces of Ukraine and more are considered.

The logical-semantic method made it possible to form, deepen and concertize the categorical apparatus of research, in particular, to define the concepts of "territorial defense of Ukraine" and "administrative and legal regulation".

Using the comparative legal method, the peculiarities of the legal regulation of territorial defense in foreign countries (Poland, Romania and Finland) are analyzed. In particular, it was established that in connection with the aggression of the Russian Federation in eastern Ukraine in recent years, the defense capabilities of these countries has improved.

Methods of analysis and synthesis made it possible to identify the main tendencies and problems in the field of territorial defense of Ukraine, to develop certain approaches to improve the regulatory framework in this area.

\section{RESULT AND DISCUSSION}

\section{Analysis of recent research and publications}

Various issues related to the administrative and legal support of the appropriate level of territorial defense in Ukraine and the specific features of this process have been the subject of research by many scholars. Directly the issues of consideration, study and systematization of conceptual categories in the field of territorial defense, comparison of the domestic territorial defense system with effective systems in the same field, which are available among democratic and developed countries, have been the subject of research by many scientists.

However, the lack of proper coordination of relevant scientific developments does not contribute to the proper scientific and legal support of the security and defense sector, which requires the active participation of scientific institutions, educational institutions and research institutions of the security and defense sector of Ukraine in organization and implementation of common fundamental and applied research and development. The legal problem of institutional and organizational support of military law 
enforcement, restoration of the system of military jurisdiction and military justice is urgent (Prokhorenko \& Bogutskyi, 2019).

\section{Main part}

The Ukrainian state defines the right to life and health of a person and a citizen as its highest value. In particular, this thesis is enshrined in Article 3 of the Constitution of Ukraine (1996). Domestic authorities and institutions are obliged to properly ensure all the inalienable rights and legitimate interests of individuals. The sphere of defense is no exception.

Although the Ukrainian defense sector is currently undergoing a period of qualitative gains and fundamental improvements, it still needs to overcome considerable difficulties in order to be able to effectively cope with various present challenges. Taking into account modern realities, the state and society must, by working together, find and introduce into the structure of the domestic defense sphere the latest, scientifically sound approaches to the formation of military and security organization of the state. Equally, important will be the functioning of existing and potential mechanisms to protect Ukraine's national interests from current and future challenges and threats.

Constitutional reform should become the basis for improving the status and activities of the Armed Forces of Ukraine. In this sense, the experience of the Republic of Estonia is attractive, which in Chapter 10 of the Constitution of 28 June 1992 "National Defense" established the obligation of Estonian citizens to participate in national defense, defined the status of the Defense Forces, their leadership. The Constitution of the Republic of Lithuania of 25 October 1992 also regulates similar issues in Chapter 13 "Foreign Policy and National Defense". The Constitution of the Republic of Macedonia, which provides for a separate section 7, entitled "The Defence of the Republic and States of War and Emergency", the Constitution of the Republic of Hungary, which contains Chapter 8 "Armed Forces and Law Enforcement Agencies", the Constitution of the Republic of Uzbekistan, containing Chapter 26 "Defense and Security", regulate this area of public relations in more detail (Golovatyi, 1996; Kolodii, 2019, p. 45).

Among the most important regulations governing the creation, reorganization and daily operation of Ukrainian state defense policy, including military organization, is the Law of Ukraine "On Defence of Ukraine" of 06.12.1991. The importance and priority of this law is characterized by the fact 
that it indicates important areas and principles of existence of the defense system of Ukraine.

Among other things, the above legal act sets out the basic principles of state defense, as well as the regulatory division and legislative consolidation of powers and functions between those state bodies that are involved in the processes of state defense. In addition to outlining such global issues and areas of activity of all military and security government agencies, this law specifies an exclusive list of basic functions and tasks of military administration, local administration, local government, rights and responsibilities of enterprises, institutions, organizations and officials, as well as the rights and responsibilities of citizens of Ukraine in the area of defense.

In addition to the above statements, it should be emphasized that Article 2 of the Law of Ukraine "On Defense of Ukraine" describes the essence of the main components (foundation) of Ukraine's defense. According to this article, the level of alert quality criteria of all state bodies, organizations and institutions involved in the defense process, which include, among others, central executive bodies and units of local state administrations, as well as local governments, are defined.

The key tasks of these bodies are their preparedness for the rapid implementation of a unified system of civil protection, as well as the creation of all necessary conditions for the optimal adaptation of the national economy to the realities of wartime. Among other equally important tasks, they call the maximum assistance in rejection an armed aggressor, as well as regular checking the readiness of the population and territorial communities existing in various administrative-territorial units of the state in defense and defense processes.

Despite the fact that the domestic legislation still does not clearly prescribe the measures that should be aimed at the effective organization of defense in Ukraine, nevertheless, at least the general priority areas of state institutions are indicated. First of all, these include work on the qualitative improvement of the management system of the entire structure of the armed defense of the sovereignty and territorial integrity of Ukraine.

Aiming to achieve the North-Atlantic Alliance's (NATO) generally accepted security and defense standards as the most sophisticated and highest in the world requires a lot of diligent work. Taking into account the fact that such strength and greatness of NATO lies not so much in modern missiles and fighters, but above all in the world's best level of complex interaction between 
all elements and parts of the defense system, both each member of the alliance and the whole alliance in general.

In order for the state to be adequately prepared for the armed defense of its national interests in the future probable conflict with the aggressor, it will be necessary to bring to the most up-to-date level all possible ways and methods of timely identification of potential risks and threats to Ukraine's sovereignty and territorial integrity. In turn, the key elements of the above-mentioned process of "threat detection" can be called a professional and instant analysis of current and future threats, as well as a clear system of scientific forecasting of these threats and challenges.

The official enshrinement in the Constitution of Ukraine of the country's course for joining the EU and NATO as an equal member has been an extremely positive thing in recent times (Law of Ukraine, 2019). In particular, joining NATO will be the most useful thing for Ukraine's state defense capability. This statement is based on the indisputable reality that this alliance is now the most powerful military organization in the world and plays a stabilizing role as a guarantor of democratic processes and the rule of law throughout the globe.

The ongoing armed conflict has significantly intensified the renewal of military legislation, as recurrent threats objectively necessitate the search for adequate ways to counter, including through a profound transformation of the structure of the Armed Forces of Ukraine, achieving interoperability with the armed forces of NATO member states. Therefore, no less important aspect is the legislative support of the reform process of the Armed Forces of Ukraine, creating the necessary conditions for adaptation of legislative, conceptual and doctrinal documents to NATO standards, which is noted in the National Security Strategy of Ukraine and Military Doctrine of Ukraine (Kotlyarenko, 2019, p. 28).

In addition to the already mentioned absolute advantages of membership in the North Atlantic Alliance, it is worth emphasizing others, which are also no less important. It is about essential improvement, with the help of western partners of Ukraine, of activity of domestic armed formations. Among other things, this will allow all bodies involved in the defense of the state from the aggressor to significantly improve their combat potential by optimizing their hierarchical structures in the field of governance and immediate and independent decision-making.

According to paragraph 3.4. The Strategic Defense Bulletin of Ukraine, enacted by the Decree of the President of Ukraine of 6 June 2016 № 240/2016, 
the legal support of reform measures is defined. To ensure the implementation of defense reform in Ukraine, the gradual increase of operational capabilities of the Armed Forces of Ukraine, other components of the defense force, the implementation of NATO standards and more rational use of 40 defense resources it is expected to amend the laws of Ukraine and other regulations in these areas (Strategic Defense Bulletin of Ukraine, 2016).

Legal support can be considered as (Prokhorenko, 2019, p. 40):

1. The function of the subjects of public relations.

2. A separate type of activity, as an organizational and legal measure.

3. A guarantee of legality.

4. A separate task of the state, public authority or its structural unit.

5. A set of organizational and legal measures for regulation, proper application and implementation of legal norms in order to ensure legality in the activities of public authorities and others.

Unification of national norms and principles of military organization of the state with NATO norms and standards requires following the current military "trends" of this organization, i.e. focusing most of the resources allocated for defense needs on current areas of countering the aggressor. For example, based on the assumption that special units are currently considered to be one of the most valuable in operational and strategic combat operations, a logical step on the part of the Ukrainian authorities would be to pay attention and funds to the harmonious development of this particular combat element. After all, it is well-known that the ability to correctly, and most importantly, to timely choose the most important method of confronting the aggressor for the modern sociopolitical situation is naturally considered the main key to victory in any conflict (Decree of the President of Ukraine, 2015).

Addressing issues, related to the organization of territorial defense one way or another, as well as its administrative and legal regulation, it is necessary to stress such an important point in this issue as the imposition of martial law. Moreover, the issue of introducing this regime both on the entire territory of the state and on its separate administrative-territorial units is extremely relevant and in need of its legal regulation on the part of domestic legislators.

Thus, the essence of martial law is interpreted by scholars as a special legal regime imposed in the state as a whole or in its individual parts in case of armed aggression against the integrity and sovereignty of the country, or a 
direct threat of such danger. This regime provides the relevant public authorities, military command and local authorities with the powers necessary to deal with threats and ensure national security, and, in addition, imposes temporary restrictions of various kinds on the activities of the media, public organizations and political parties, even in some way suspends some norms and provisions of the Constitution, thereby for some time narrowing the scope of guaranteed and protected by the state inalienable rights, freedoms and legitimate interests of man and citizen. The day-to-day operation of legal entities, both foreign and Ukrainian, may also be subject to such temporary restrictions.

Despite the fact that such restrictions are temporary, as well as caused by the significant likelihood of a certain threat to the existence of the entire state, the law governing martial law must comply with certain norms of the rule of law. In particular, the terms of the same prohibitive regulations that temporarily restrict the constitutional rights and freedoms of citizens, as well as the rights and legitimate interests of legal entities, must be clearly defined and prescribed in the legal act.

In the context of the study, it should also be emphasized that a clear, direct and unambiguous interpretation of forced restrictions is no less important than a clear definition of the term. That is, the guarantee of the impossibility of using martial law, and most importantly - the restrictions of the rights and freedoms provided by the legal regime of this state, for any usurpation of power by anyone and the impossibility of criminal activity on the basis of this regime in general (Law of Ukraine, 1992).

According to numerous studies, the development of the Armed Forces is taking place in other European countries. For example, the Territorial Defense Force (TDF) was formed as the fifth branch of the Polish Armed Forces officially on 1 January 2017, according to the Act of 16 November 2016, amending the Act on the Universal Obligation to Defend the Republic of Poland and certain other acts (Maziarz, 2020). As noted by P. Kler, B. Szczesniak, A. Anyzewska and J. Bertrand (2019), among all types of the Armed Forces of the Republic of Poland, the name of the Territorial Defense Force reflects its character and purpose to the greatest extent. The goals and tasks set for it depend on the specific defense needs of the state.

In his research, Dan Plăvițu (2016) noted that the fear of new " hybrid warfare" in the south-eastern flank of NATO, provoked by the Russian Federation following the Ukrainian model, alongside whit the circumstances offered by the existent frozen conflict in the neighborhood of Romania, with the 
evident process of Russian remilitarization in the Black Sea area, opened a serious debate in Romania about the need of recreating, training and endowing a National Reserve Force asked to manage the so-called concept of Territorial Defence. The role of TD is to support and to enhance the actions of the active defense forces through specific activities and to ensure a timely and efficient operation in order to prevent and reduce the consequences of an unexpected aggression over the country.

According to the Finnish Ministry of Defence website, the Defence Policy Department is responsible for assessing the development of the security and defence policy environment. The Department provides the grounds for defence policy and the planning basis for the defence forces. It deals with matters concerning general national defence capability, conscription, military crisis management, peace support operations and disarmament and arms control. The department consists of four units (Laird, 2018): 1) Defence Cooperation Unit; 2) National Defence Unit; 3) Research Unit; 4) Scientific Advisory Board for Defense.

\section{CONCLUSIONS}

Despite the significant successes of Ukrainian society that have been achieved by the public in creation a modern, powerful and combat-ready armed forces, Ukraine's defense system still has its shortcomings. In particular, the system of coordination and communication between domestic military units, territorial defense bodies, local authorities and self-government bodies, administrations of enterprises, organizations and institutions is still quite outdated.

In order to quickly and efficiently overcome all the obstacles that slow down the development of Ukraine's defense capabilities, the domestic community, and especially the leadership of the state, should focus their attention and all available resources on several important areas. Adding to the coordinating joint actions, it is also important to introduce clear and unambiguous legislative support for the national territorial defense system.

\section{References:}

Golovatyi, S. (ed.) (1996). Constitutions of the new states of Europe and Asia. Kyiv: Ukrainian Legal Foundation; Publishing house "Law".

Kler, P., Szczesniak, B., Anyzewska, A. \& Bertrand, J. (2019). Assessment of nutritional knowledge of soldiers of the Territorial Defense Force of the Polish 
Armed Forces. The 13th European Nutrition Conference, FENS 2019, was held at the Dublin Convention Centre, 15-18 October 2019. DOI: 10.1017/S0029665120002591.

Kolodii, A. M. (2019). Constitutional reform in Ukraine is a means to improve the status and activities of the Armed Forces of Ukraine. Legal support of troops (forces) as a type of support of the Armed Forces of Ukraine and other components of the defense forces. National Security Law and Military Law: History, Present and Prospects: Proceedings of the Round Table (Kyiv, 28 March 2019). Kiev.

Kotlyarenko, O. P. (2019). Organizational support for the adaptation of military legislation to NATO standards. National Security Law and Military Law: History, Present and Prospects: Proceedings of the Round Table (Kyiv, 28 March 2019). Kiev.

Laird, R. (2018). Crafting a Way Ahead for the Defense of Finland: The Perspective of the Head of the Defense Policy Branch in the Ministry of Defence, Finland. Retrieved from https://sldinfo.com/2018/02/crafting-a-way-ahead-for-thedefense-of-finland-the-perspective-of-the-head-of-the-defense-policybranch-in-the-ministry-of-defence-finland/

Maziarz, B. (2020). The Territorial Defense Force in the fight against terrorism institutional and legal issues. Scientific Journal of the Military University of Land Forces. Volume 52. Number 1(195), 69-75.

On Amendments to the Constitution of Ukraine (Regarding the Strategic Course of the State for Acquiring Full-Fledged Membership of Ukraine in the European Union and in the North Atlantic Treaty Organization): Law of Ukraine of 07.02.2019 № 2680-VIII. Information of the Verkhovna Rada of Ukraine. 2019. № 9. Art. 50.

On conscription and military service: Law of Ukraine of 25 March 1992 № 2232XII. Information of the Verkhowna Rada of Ukraine. 1992. № 27. Art. 385.

On Defence of Ukraine: Law of Ukraine of 06.12.1991 № 1932-XII. Information of the Verkhowna Rada of Ukraine. 1992. № 9. Art. 107.

On the decision of the National Security and Defense Council of Ukraine of 2 September 2015 "On the new version of the Military Doctrine of Ukraine": Decree of the President of Ukraine of 24.09.2015 № 555. Retrieved from https://zakon.rada.gov.ua/laws/show/555/2015. 
On the decision of the National Security and Defense Council of Ukraine of 4 March 2016 "On the Concept for the Development of the Security and Defense Sector of Ukraine": Decree of the President of Ukraine № 92/2016 of 14 March 2016. Retrieved from https://www.president.gov.ua/documents/ 922016-19832.

Plavitu, D. (2016). Territorial defence as a part of the Romanian National Defence System. Strona. 2(7), 219-227. Retrieved from http://cejsh.icm.edu.pl/cejsh/element/bwmeta1.element.desklightcc8c60c8-9635-46cc-a155-acbcb820fbe3/c/AP.VII_Plavitu.pdf

Prokhorenko, M. M. (2019). Legal support of troops (forces) as a type of support of the Armed Forces of Ukraine and other components of the defense forces. National Security Law and Military Law: History, Present and Prospects: Proceedings of the Round Table (Kyiv, 28 March 2019). Kiev.

Prokhorenko, M. M. \& Bogutskyi, P. P. (ed.) National security law and military law: history, modernity and prospects: Proceedings of the Round Table (Kyiv, 28 March 2019) / Ministry of Defense of Ukraine, The National Defense University of Ukraine named after Ivan Cherniakhovskyi; National Academy of Legal Sciences of Ukraine, Scientific Research Institute of Informatics and Law. Kyiv: FOP Yamchynskyi O. V.

Strategic Defense Bulletin of Ukraine, enacted by the Decree of the President of Ukraine of June 6, 2016 № 240/2016 // Official Gazette of the President of Ukraine. № 17, 22.06.2016, Art. 10.

The Constitution of Ukraine. Information of the Verkhovna Rada of Ukraine. 1996. № 30. Art. 3.

Yaniuk S. (2019). Implementation of foreign experience of territorial defense state regulation mechanisms. Public Administration and Local Government. Issue 4(43), 97-105. 